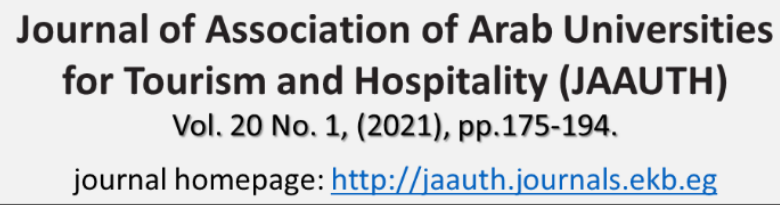

\title{
The Effect of Applying Technology at the Guest Room on the Guest's Choice of the Hotel: Applied to Luxor \& Aswan Governorates' Hotels
}

\section{Hany Atef Kozmal}

Mahmoud Ahmed Mohamed Saleh

Maisa Fathey Abd El-Latief

Hotel Management the Higher Institute for Tourism and Hospitality management Egoth Luxor.

\begin{tabular}{|c|c|}
\hline ARTICLE INFO & Abstract \\
\hline $\begin{array}{l}\text { Keywords: } \\
\text { Technology; Guests' } \\
\text { rooms; Applying } \\
\text { technology; Guest } \\
\text { loyalty. } \\
\text { (JAAUTH) } \\
\text { Vol. 20, No. 1, } \\
\text { (2021), } \\
\text { PP. 175-194. }\end{array}$ & $\begin{array}{l}\text { There has recently been a call for revisiting the effect of } \\
\text { technology on guest experience in hotels. Technology has } \\
\text { been gradually and usually applied to the hospitality } \\
\text { industry. Hence, the present study identifies the effects of } \\
\text { the agreement of the guest room technology adoption the } \\
\text { perspective of hotel guests on their choice of the hotel. A } \\
\text { questionnaire survey was adopted to collect data from guests } \\
\text { in the four and five stars' hotels in Luxor and Aswan } \\
\text { governorates to investigate the impacts of individual-level } \\
\text { importance on the technology acceptance in guests' rooms. } \\
\text { This study aims to investigate the special effects of } \\
\text { advanced technology in hotels' rooms on guest loyalty. This } \\
\text { study observed in-room technologies and identified the ones } \\
\text { realized to be mission critical for the hotel guests. It also } \\
\text { determined the differences in guest empowerment } \\
\text { technology preferences and expectations across generations } \\
\text { and travel frequency. Moreover, it investigated whether the } \\
\text { quality of in-room technologies impressions guests' decision } \\
\text { in choosing a hotel. The data were collected through } \\
\text { personal meetings with the guests, hotels, as well as Google } \\
\text { drive, hotels mails and social media. (500) questionnaires } \\
\text { were distributed, only (428) samples were correctly ready to } \\
\text { be analyzed. Important finding of this study was that a } \\
\text { plurality of respondents informed that the availability of new } \\
\text { guest-room technologies would favorably impact their } \\
\text { decision to choose a hotel. }\end{array}$ \\
\hline
\end{tabular}

\section{Introduction}

Today technology is a part of normal life (Abbasi et al., 2015). Nowadays, we can see the strong entry of technology in all aspects of our lives, especially in the areas of commercial, industrial and services sectors (Bilgihan et al., 2016). This technological development has become very effective on the national economy in all countries worldwide (Cobos et al., 2016). The hospitality industry must keep abreast with the 
advancement with which these changes occur as the hotel technologies are continuously being introduced (Dieck et al., 2017). In the recent age, an organization's success depends on how much it knows about its guests and their needs (Ivanov et al., 2018). The efforts to improve hotel service and to increase its quality and efficiency stimulate and multiply a variety of technological innovations. Technologies play important part not only for the guests, but for the owners of hotels as well (Dalgic and Birdie, 2020).

Only by understanding hotels' guests' requests can arrangements create effective plans to survive in this rapidly changing and aggressive universal market (Jung et al., 2014). Like other arrangements, today's hotels are faced with a number of difficulties, from a weak economy to rigorous contest (Kucukusta et al., 2014). Technologies assist hotels to offer better service to their guests. While guests' request for technology in hotels is on the rise, hotels' technology plans continue to develop (Gunarathne, 2014). Therefore, it is serious for hotel managers to understand which in-room technologies guests' estimate and which they consider dispensable (Kim, 2016). The findings of this study will display which guests' rooms technologies are perceived as mission critical by the guests and the changes in guests' technology requests and expectations across age groups (Kansakar et al., 2019).

\section{Objectives of the Study}

The major objective of this study is to describe the impact of applying technology at the guest room on the guest's choice of the hotel, to discover the importance ratings of in-room technology enjoyment when selecting hotels. More specifically, the study's objectives are:

1. To explore and compare the dimensions of in-room technology amenities that guests understand to be important in their choice of a hotel and their perceived achievement of those in-room technology enjoyment.

2. To determine differences in preferences and achievement of in-room technology facilities among guests.

3. To identify the potential impact of in-room technology facilities on guests satisfaction.

\section{Literature}

Technology is the greatest force leadership change in the hospitality industry and would continue to alter the way the industry conducts business in the future (Kandampully and Suhartanto, 2000). Recent hotels appeal to guests in several different ways, including the quality of guest facility, the amenities on offer, the design of the property, but also through hotel technology too (Higley, 2007). Hospitality technology has become increasingly important and can be found from the mid-scale to luxury hotel segments (Erdem et al., 2009). It has become important to continue to identify the amenities, services, and technology applications that guests demand from hotels (Cobanoglu et al., 2011). Technological improvement promotes guest satisfaction, develops hotel service quality and provides opportunities for hotels to increase profitability and competitiveness (Almomani et al., 2017). Technology can simultaneously reduce labor costs; provide fast and standardized services. Thus, a 
hotel can take opportunities to regularly develop technology improvement, there by differentiating itself from and profit competitive advantages against competitors (Beldona et al., 2018).

\section{Understanding Guests' Choice}

Understanding guests' choice is critical (Beatson et al., 2006). Guests select a product from among a set of alternatives using choice standard that they perceive to have the best potential for pleasurable their needs (Beldona and Cobanoglu, 2007). Several of the hotel's choice studies have focused on the cognitive attributes used to choose a hotel and have examined the differences between hotel high-quality attributes, depending on the type of leisure business, gender, hotel category and technology (Bilgihan et al., 2010). Making things even more challenging tasks, potential market offerings in the hospitality industry have grown increasingly complex due in great measure to advances in technology that allow guests to strategically assess the relative budgets of different alternatives (Kuo et al., 2012).

\section{Technology and Hotel Industry}

Hotels use technology as a value-added facility to their guests (Verma et al., 2007). By doing so, hotels can create differentiation, enhance guest contentment and structure lasting loyalty among guests (Munyan, 2008). Guests demand technology applications and amenities before, during, and after they stay in hotels (Lee et al., 2009). With the development of modern technology, the need for their application becomes the key for the competitiveness of hospitality industry (Lan, 2014). The hospitality industry is striving overwrought to be as innovative as possible (Bilgihan et al., 2016). It is evident in the fact that even mid-priced hotels have started focus on design and aesthetic appearance rather than just focusing on providing functional benefits (Beldona et al., 2018).

\section{Guests' Rooms Technologies}

Guests have many choices when selecting hotels (Prayukvong et al., 2007). In this highly competitive environment for guests, managers should understand their guests' necessary needs in order to keep guests and attract new guests (Marlin, 2008). New technology for the global hospitality industry has debuted at a astounding rate and experts said they expect many of the new technology created in the past decade to be standard soon (Schrier et al., 2010). Managers enable to offer a meaningful set of guestroom technology applications to guests (Ruiz et al., 2011). Since guests have options when selecting to visit the hotel, they may be increasingly expecting a variety of choices for entertainment in their rooms (Ivanov et al., 2017). The improvements in the guests' rooms' technology over the last few years has resulted in an increased agreement by guests and now this may heighten the importance of in-room offerings in hotels as today's luxury is tomorrow's expectancy (Lukanova and Ilieva, 2019).

Cobanoglu et al. (2006) said that if hotels need to get a competitive quality, they should realize that the next generation of technology savvy business guests would support the hotels where these emerging technologies are available and are intended to improve guests overall knowledge. Chathoth (2007) added that in-room technology is a revenue producing chance for hotels. In-room technologies include: (1) Keyless 
Entry, where gone are the days of misplacing a keycard and being locked out of a room (Kansakar et al., 2019). In modernistic hotels, a guest's smartphone will soon substitute the cards that we currently use to unlock hotel doors (Ivanov et al., 2017). Hotels will gradually install smart room access systems that let guests to unlock their doors by simply swiping their phones across a keyless pad on the door (Ivanov et al., 2018). Another innovatively way to offer a keyless skill is through fingerprintactivated room entry classifications and retina scanning devices (Beldona et al., 2018). (2) Televisions, where this is already a reality at some luxury hotels across the globe, where guests can watch high-definition TV in mirrors (Kansakar et al., 2019). (3) Smart Thermostats, where hotels are gradually adding thermostat technology that will allow guests to adjust the temperature in their rooms with a smartphone, even if they aren't on the premises (Dieck et al., 2017). (4) Texting Concierge, where at several hotels, guest can now communicate their needs to the staff through a smartphone (Law et al., 2020). (5) Streaming Devices to TV, where guests can stream their computers, phones, or tablets directly to the high definition televisions in their rooms. This allows guests to task on these screens, or to use them to watch satisfaction via streaming services such as Hulu and Netflix (Dalgic and Birdie, 2020). (6) Smart Lighting, where hotels currently let guests to also dim the lights in their room remotely (Cobos et al., 2016). (7) MP3 Docking Stations, where this is one of the more prevalent technologies, seeing as a good numbers of guests are coming to see it as standard (Kansakar et al., 2019). (8) High Speed Internet, where all hotels provide guests with access to high quickness internet (Beldona et al., 2018). Hotel guests imagine being able to connect to the internet seamlessly; and without too several interruptions, leading hotels to invest in better and faster Wi-Fi infrastructure (Kansakar et al., 2019). (9) Light sensors, where these sensors turn on when a guest arrives a room, and they turn off when the room has left a while without any motion (Cobos et al., 2016). (10) Robots, where we're not quite there yet, but some hotels are offering additional futuristic skills, with robots delivering any items required through room service to a guest's door (Lukanova and Ilieva, 2019). These kinds of digital systems not only create it easy for hotel staff to deliver items to guests, but it also offers a forward-facing digital ability to communities who stay at the hotel (Ivanov et al., 2018). Infrared scanners are also used to minimize disruptions relating to housekeeping (which is a common complaint from customers) (Kansakar et al., 2019). Instead of hanging a 'Do Not Disturb' sign on doors or having staff wake up guests with knocks and phone calls, hotel staff can take a more innovative approach by using infrared scanners that will detect body heat within a room and tell staff that they should rather come back later if the room is currently occupied (Dalgic and Birdie, 2020). (11) Mobile communication and automation, where guests want to be able to do all from checking in at a venue's automated kiosk to ordering room service with a digital device instead of standing in queues and movable around the hotel premises to order food (Tavitiyaman et al., 2020). Technology study found that guestroom technology was the greatest important technology area for guests but it did not perform that well to the agreement level of the guest (Law et al., 2020). 


\section{Effects of Applying Technological Innovations}

Technology has advanced its uses have increased to the point that people don't even realize that the technology is there (Lee et al., 2003). With guests' approval of the constant presence of technology has come a natural increase in gusts' usage of technology applications (Inge, 2006). As guests have become more technologically savvy establishments have begun to take benefit of these expertise (McMullen, 2006). This allows guests to use technology to aid in the creation and consumption of many products and service. The guest is able to perform the steps necessary to achieve the exact outcomes that they wish (Cobanoglu, 2009). When guests receive their expected outcomes they tend to have higher levels of satisfaction as well as a feeling of improved service quality (Zabkar et al, 2009).

\section{Research Hypotheses}

H1: Applying technology at the guest room has an effect on the guest's choice of the hotel.

H2: The top ranking of guest priorities regarding the role of applying technology at the guest room on the guest's choice of the hotel have positive influences in each other.

H3: The guest priorities have positive influence with the guest perception in accordance to the facilities technological amenities.

\section{Methodology}

The planning and development for the current research study began in September 2019 and continued through August 2020. During that time a review of literature was conducted, research questions and hypotheses were developed, and data collection procedures were determined. A survey instrument was formulated, and data analysis techniques were selected.

\section{The Characteristics of the Investigated Hotels}

The study was conducted on a sample of (20) hotels from Upper Egypt Luxor and Aswan hotels. The choice of the hotels was due to category and the more availability. The characteristics of the investigated hotels are as follows in table (1).

\section{Table 1}

The Characteristics of the Investigated Hotels.

\begin{tabular}{l|l|c|c|c|}
\hline No & \multicolumn{1}{|c|}{ Hotel name } & Total Rooms & Category & Location \\
\hline 1. & Hilton Luxor Hotel and SPA & 236 & 5 stars & Luxor \\
\hline 2. & Luxor Sheraton Hotel Resort & 290 & 5 stars & Luxor \\
\hline 3. & Maritim Jolie Ville Kings Resort & 334 & 5 stars & Luxor \\
\hline 4. & Sofitel Karnak Hotel & 347 & 5 stars & Luxor \\
\hline 5. & Sofitel Winter Palace Hotel & 234 & 5 stars & Luxor \\
\hline 6. & Sonesta st. George Hotel Luxor & 322 & 5 stars & Luxor \\
\hline 7. & Steigen Bergernile Palace Hotel & 304 & 5 stars & Luxor \\
\hline 8. & Akhetaton Village & 144 & 4 stars & Luxor \\
\hline 9. & Almoudira Hotel & 54 & 4 stars & Luxor \\
\hline 10. & El Luxor Hotel & 306 & 4 stars & Luxor \\
\hline
\end{tabular}




\begin{tabular}{|c|l|c|c|c|}
\hline 11. & Iberotel Luxor Hotel & 185 & 4 stars & Luxor \\
\hline 12. & Pyramisa Isis Luxor Hotel & $480+$ time share & 4 stars & Luxor \\
\hline 13. & Amoun Village & 50 & 5 stars & Aswan \\
\hline 14. & Mövenpick Resort Aswan & 244 & 5 stars & Aswan \\
\hline 15. & Pyramisa Isis Island Hotel & $447+$ time share & 5 stars & Aswan \\
\hline 16. & New Cataract Hotel & 62 & 5 stars & Aswan \\
\hline 17. & Sofitel old Cataract Hotel & 76 & 5 stars & Aswan \\
\hline 18. & Basma Hotel Aswan & 210 & 4 stars & Aswan \\
\hline 19. & Cleopatra Hotel & 130 & 4 stars & Aswan \\
\hline 20. & Isis Hotel Aswan & 104 & 4 stars & Aswan \\
\hline
\end{tabular}

\section{Questionnaire Pre-testing}

To increase the reliability and validity of the questionnaire, and to measure its attributes' adequateness, clearness and ease of understanding, the English questionnaire is reviewed by some academic scholars.

\section{Questionnaire design}

Questionnaire was evaluated using a five-point likert scale ranging from $1=$ 'No opinion' to 5= 'Very Important'. The questionnaire form consists of sociodemographic and general questions such as: Age, education and experience about the floating hotels' general managers, in addition to, general information about the floating hotels. The questionnaire prepared for this study is based on a comprehensive literature review and consistent with the objectives of the study. The questionnaire formulated through divided into four main dimensions, in addition general data on hotels: The first dimension is "In-Room Technologies" and contains (18) questions. The second dimension contains (12) questions regarding "Comfort Technologies" at the rooms' guests in the hotels. Dimension three: "Business essentials". It contains (5) questions. Fourth dimension: "Internet access". This part consists of (2) questions.

\section{Data processing}

The data in the research were processed using SPSS Version 21.0 to interpret the results of the questionnaires.

\section{Results and Discussions}

The responses obtained from the questionnaires are shown as follows:

\section{Reliability of the Scale}

In terms of the reliability of the survey scales, in this study, Cronbach's coefficient alpha was used to measure the internal consistency of the scale. The higher value of the Cronbach's coefficient Alpha indicates a greater value. In that sense, all the values of the Cronbach's coefficient Alpha in this study are above the minimum level which was considered "acceptable" in most social science situations. The Cronbach's Alpha reliability was computed, and the tests showed that the reliability coefficients for all the instruments were above (0.98), which indicated that the instrument was reliable for being used. Cronbach's Alpha for all survey instruments was shown in the following table (2): 
Table 2

Reliability Statistics.

\begin{tabular}{|c|c|c|}
\hline Cronbach's Alpha & No. of Items & No of Item questionnaire \\
\hline 0.985 & 42 & 428 \\
\hline
\end{tabular}

\section{Results Analysis}

The total numbers of the questionnaire sample, that received by (A personal meetings with the guests, hotels, as well as Google drive, hotels mails and social media), were (500); only (428) samples were correctly ready to be analyzed in studying the effect of applying technology at the guest room on the guest's choice of the hotel.

\section{Questionnaire form Analyses}

Question no. (1) Regarding: Demographic data analysis.

This section was concerned with the demographic data of the respondents including: age, gender, as well as marital status (Table 3).

The results indicate that:

- The majority of the respondents were from 35 to 45 years old.

- The majority of the respondents were female.

- The majority of the respondents were single.

Table 3

Respondent's Demographic Data Analysis.

\begin{tabular}{|l|l|c|c|}
\hline \multicolumn{2}{|l|}{ Personal data } & Frequency & Percent (\%) \\
\hline \multirow{4}{*}{ Age } & Under 25 years & 56 & 13.1 \\
\cline { 2 - 4 } & From 25 to under 35 years & 44 & 10.3 \\
\cline { 2 - 4 } & From 35 to 45 years & 146 & 34.1 \\
\cline { 2 - 4 } & Over than 45 & 182 & 42.5 \\
\cline { 2 - 4 } & Total & 428 & 100.0 \\
\hline \multirow{5}{*}{ Gender } & Male & 171 & 40.0 \\
\cline { 2 - 4 } & Female & 257 & 60.0 \\
\cline { 2 - 4 } & Total & 428 & 100.0 \\
\hline \multirow{4}{*}{ Marital Status } & Single & 221 & 51.6 \\
\cline { 2 - 4 } & Married & 183 & 42.8 \\
\cline { 2 - 4 } & Other & 24 & 5.6 \\
\cline { 2 - 4 } & Total & 428 & 100.0 \\
\hline
\end{tabular}

Question no. (2): Please, rank level of priorities regarding the effect of applying technology at the guest room on the guest's choice of the hotel?

This question was concerning to the guest priorities about the effect of applying technology at the guest room on the guest's choice of the hotel. This part included the attribute analysis through guests' perspectives in terms of guest priorities about the effect of applying technology at the guest room on the guest's choice of the hotel. The attributes were divided into (5) sections; why the guest choose the hotel; Dimension (1): In-room technologies; Dimension (2): Comfort technologies; Dimension (3): Business essentials; Dimension (4): Internet access. Furthermore, this part presented 
the ranking of attributes in each section. Table (4) showed guests' perspectives regarding the effect of applying technology at the guest room on the guest's choice of the hotel.

\section{Why did the guest choose the hotel?}

- In accordance why the guest chooses the hotel the1st ranking position were the price with weighted average (99.63\%), a mean (4.98) and std. deviation (0.13).

- Regarding the $2^{\text {nd }}$ ranking position was quality by $(99.07 \%)$ as weighted average with a mean (4.953) and std. deviation (0.21).

- Concerning the facilities technological amenities was 3rd ranking position for the guest perceptions by weighted average (98.50\%), with a mean (4.92) and std. deviation (0.26).

- The $4^{\text {th }}$ ranking position by $(97.57 \%)$ was as important weighted average referred to the Services, std. deviation was (0.32) and mean (4.87).

- Concerning the location, results showed that $(97.20 \%)$ were as important as weighted average. A mean was (4.86) and std. deviation (0.34).

- These results agreed with Lee et al. (2003), Prayukvong et al. (2007), Zabkar et al. (2009) and Kuo et al. (2012).

\section{Dimension (1): In-Room Technologies}

- Concerning the in-room technologies. Coffee/tea making facilities was the $1^{\text {st }}$ ranking position for the guest perceptions in the investigation as follows: (97.57 $\%$ ) were as weighted average, with a mean (4.87) and std. deviation (0.32).

- Regarding the in-room Pay-Per-View (PPV) movies, was the $2^{\text {nd }}$ ranking position, $(96.64 \%)$ were as weighted average with a mean (4.55) and std. deviation (0.49).

- In terms of room facilities, was the $3^{\text {rd }}$ ranking position for the guest perceptions in the investigation, the weighted average was (96.64\%), with a mean (4.83) and std. deviation (0.37).

- Concerning the hair dryer, was the $4^{\text {th }}$ ranking position, with weighted average (96.64\%), a mean (4.83) and std. deviation (0.37).

- Regarding the home with iPod and radio, results showed that $(95.33 \%)$ were as important as weighted average. A mean was (4.76) and std. deviation (0.42).

- These results agreed with Verma et al. (2007), Cobanoglu (2009), Abbasi et al. (2015), Bilgihan et al. (2016), Almomani et al. (2017) and Beldona et al. (2018).

\section{Dimension (2): Comfort Technologies}

- Concerning the air conditioning was the $1^{\text {st }}$ ranking position of the guest perceptions in the investigation which reflected the most important came as follows: (99.07\%) was as weighted average, with a mean (4.95) and std. deviation (0.21). 
- Concerning the mobile access to hotel website (e.g., Blackberry), was the $2^{\text {nd }}$ ranking position, results showed that $(95.70 \%)$ were as important as weighted average. A mean was (4.78) and std. deviation (0.41).

- Concerning the In-room guest control panel (e.g., lights, TV, temperature, blinds, curtains, etc.) was 3rd ranking position for the guest perceptions by weighted average (95.51\%), with a mean (4.77) and std. deviation (0.41).

- The $4^{\text {th }}$ ranking position by $(95.33 \%)$ were as important weighted average referred to the CD/DVD player, std. deviation was (0 .42) and mean (4.766).

- Concerning the flat panel HD television, results showed that $(92.48 \%)$ were as important as weighted average. A mean was (4.62) and std. deviation (0.65).

- These results agreed with Munyan (2008), Marlin (2008), Lee et al. (2009) Kucukusta et al. (2014), Cobos et al. (2016), Kim (2016) Ivanov et al. (2017) and Law et al. (2020).

\section{Dimension (3): Business Essentials}

- Regarding the business center (e.g., computers, fax and copier machinery, etc.), was the $1^{\text {st }}$ ranking position of the guest perceptions in the investigation, (98.13 $\%)$ were as weighted average; with a mean (4.90) and std. deviation (0.29).

- The $2^{\text {nd }}$ ranking position by $(97.76 \%)$ accepted weighted average was in the Express check-in / check-out, with a mean (4.88) and std. deviation (0.31).

- The $3^{\text {rd }}$ ranking position by $(96.26 \%)$ weighted average was concerning In-room alarm clock, with a mean (4.81) and std. deviation (0.39).

In terms of room facilities, was the $3^{\text {rd }}$ ranking position for the guest perceptions in the investigation, the weighted average was (96.64\%), with a mean (4.83) and std. deviation (0.37).

- Concerning the easily accessible electronic outlets, was the 4th ranking position, with weighted average (94.58 \%), a mean (4.72) and std. deviation (0.44).

- Regarding the in-room telephone, results showed that $(93.41 \%)$ were as important as weighted average. A mean was (4.67) and std. deviation (0.47).

- These results agreed with Inge (2006), Chathoth (2007), Jung et al. (2014), Bilgihan et al. (2016), Beldona et al. (2018), Kansakar et al. (2019) and Law et al. (2020).

\section{Dimension (4): Internet Access}

- In terms of free High Speed Internet Access (HSIA), the 1st ranking position was for the guest perceptions in the investigation with weighted average (96.64\%), a mean (4.83) and std. deviation (0.37).

- 2 nd ranking position by $(91.54 \%)$ was as importance as weighted average of that In-room high-speed internet access. with mean (4.57) and std. deviation was (0.65). 
Table (4): Ranking Level of Priorities Regarding the Effect of Applying Technology at the Guest Room on the Guest's Choice of the Hotel.

\section{Table 4}

Ranking Level of Priorities Regarding the Effect of Applying Technology at the Guest Room on the Guest's Choice of the Hotel.

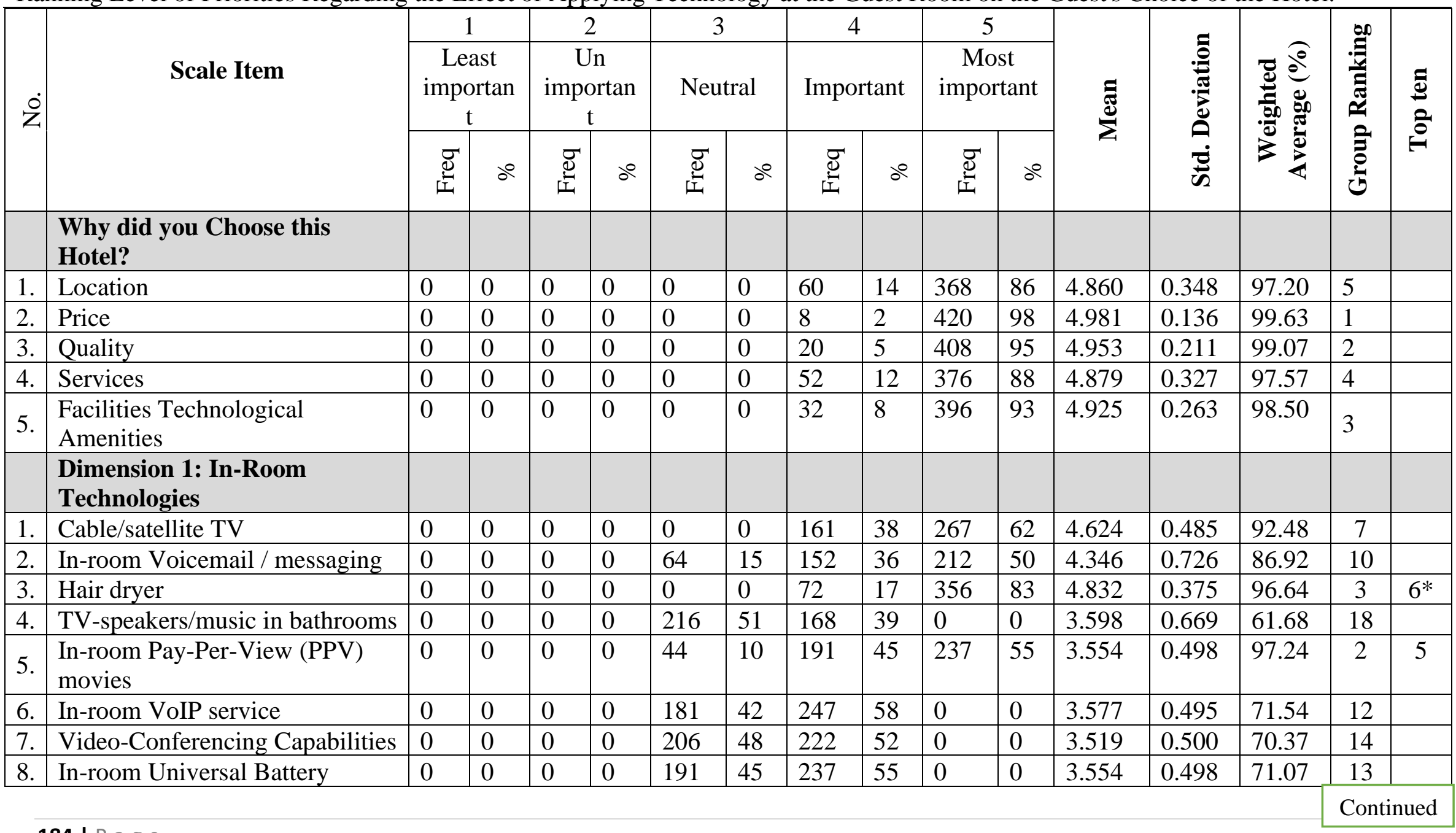




\begin{tabular}{|c|c|c|c|c|c|c|c|c|c|c|c|c|c|c|c|c|}
\hline \multirow{3}{*}{$\dot{0}$} & \multirow{3}{*}{ Scale Item } & \multirow{2}{*}{\multicolumn{2}{|c|}{$\begin{array}{c}1 \\
\text { Least } \\
\text { importan } \\
t\end{array}$}} & \multirow{2}{*}{\multicolumn{2}{|c|}{\begin{tabular}{|c|}
2 \\
Un \\
importan \\
$\mathrm{t}$
\end{tabular}}} & \multirow{2}{*}{\multicolumn{2}{|c|}{$\begin{array}{c}3 \\
\text { Neutral }\end{array}$}} & \multirow{2}{*}{\multicolumn{2}{|c|}{$\frac{4}{\text { Important }}$}} & \multirow{2}{*}{\multicolumn{2}{|c|}{ 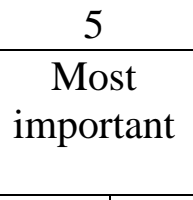 }} & \multirow{3}{*}{ 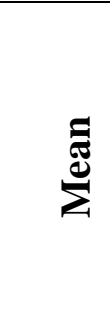 } & \multirow{3}{*}{ 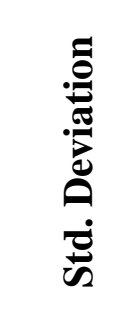 } & \multirow{3}{*}{ 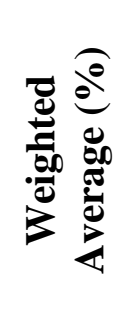 } & \multirow{3}{*}{ 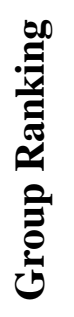 } & \multirow{3}{*}{ 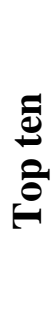 } \\
\hline & & & & & & & & & & & & & & & & \\
\hline & & 夰 & $b^{e}$ & 总 & $b^{0}$ & ర્ટ் & $b^{\circ}$ & 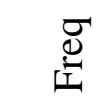 & $\delta^{0}$ & ఫ্টు & $b^{e}$ & & & & & \\
\hline & Charger & & & & & & & & & & & & & & & \\
\hline 9. & In-room Fitness System & 0 & 0 & 0 & 0 & 308 & 72 & 120 & 28 & 0 & 0 & 3.280 & 0.450 & 65.61 & 17 & \\
\hline 10 & $\begin{array}{l}\text { In-room game system (e.g. Wii } \\
\text { or PlayStation) }\end{array}$ & 0 & 0 & 0 & 0 & 0 & 0 & 84 & 20 & 344 & 80 & 4.804 & 0.398 & 96.07 & 4 & 8 \\
\hline 11. & Virtual concierge & 0 & 0 & 0 & 0 & 104 & 24 & 324 & 76 & 56 & 13 & 4.757 & 0.429 & 88.22 & 9 & \\
\hline 12. & In-room interactive table & 0 & 0 & 0 & 0 & 0 & 0 & 276 & 65 & 96 & 22 & 4.094 & 0.589 & 74.02 & 11 & \\
\hline 13. & In-room interactive mirror/wall & 0 & 0 & 0 & 0 & 56 & 13 & 56 & 13 & 316 & 74 & 4.608 & 0.708 & 92.15 & 8 & \\
\hline 14. & iHome with iPod and radio & 0 & 0 & 0 & 0 & 0 & 0 & 100 & 23 & 328 & 77 & 4.766 & 0.424 & 95.33 & 5 & \\
\hline 15. & coffee/tea making facilities & 0 & 0 & 0 & 0 & 0 & 0 & 52 & 12 & 376 & 88 & 4.879 & 0.327 & 97.57 & 1 & 4 \\
\hline 16 & $\begin{array}{l}\text { Guest Room Lock Access via } \\
\text { guest's mobile phone }\end{array}$ & 0 & 0 & 0 & 0 & 40 & 9 & 44 & 10 & 344 & 80 & 4.710 & 0.627 & 94.21 & 6 & \\
\hline 17. & Room Butler & 0 & 0 & 0 & 0 & 284 & 66 & 144 & 34 & 0 & 0 & 3.336 & 0.473 & 66.73 & 16 & \\
\hline 18. & Door Mate & 0 & 0 & 0 & 0 & 264 & 62 & 164 & 38 & 0 & 0 & 3.383 & 0.487 & 67.66 & 15 & \\
\hline & $\begin{array}{l}\text { Dimension 2: Comfort } \\
\text { Technologies }\end{array}$ & & & & & & & & & 0 & 0 & & & & & \\
\hline 1. & LCD Television & 0 & 0 & 0 & 0 & 72 & 17 & 139 & 33 & 217 & 51 & 4.339 & 0.750 & 86.78 & 8 & \\
\hline 2. & CD/DVD Player & 0 & 0 & 0 & 0 & & & 100 & 23 & 328 & 77 & 4.766 & 0.424 & 95.33 & 4 & \\
\hline 3. & Mini Bar & 0 & 0 & 0 & 0 & 48 & 11 & 128 & 30 & 252 & 59 & 4.477 & 0.689 & 89.53 & 6 & \\
\hline 4. & Air Conditioning & 0 & 0 & 0 & 0 & & & 20 & 5 & 408 & 95 & 4.953 & 0.211 & 99.07 & 1 & 1 \\
\hline 5. & Electronic Wireless Key Card & 0 & 0 & 0 & 0 & 171 & 40 & 257 & 60 & & & 3.601 & 0.490 & 72.01 & 9 & \\
\hline 6. & In-room Electronic Safe & 0 & 0 & 0 & 0 & 68 & 16 & 138 & 32 & 222 & 52 & 4.360 & 0.741 & 87.20 & 7 & \\
\hline 7. & $\begin{array}{l}\text { Mobile Access to Hotel Website } \\
\text { (e.g., Blackberry) }\end{array}$ & 0 & 0 & 0 & 0 & 0 & 0 & 92 & 22 & 336 & 79 & 4.785 & 0.411 & 95.70 & 2 & 9 \\
\hline
\end{tabular}




\begin{tabular}{|c|c|c|c|c|c|c|c|c|c|c|c|c|c|c|c|c|}
\hline \multirow{3}{*}{$\dot{\mathrm{Z}}$} & \multirow{3}{*}{ Scale Item } & \multirow{2}{*}{\multicolumn{2}{|c|}{$\begin{array}{c}1 \\
\text { Least } \\
\text { importan } \\
t\end{array}$}} & \multirow{2}{*}{\multicolumn{2}{|c|}{$\begin{array}{c}2 \\
\text { Un } \\
\text { importan } \\
\mathrm{t}\end{array}$}} & \multirow{2}{*}{\multicolumn{2}{|c|}{$\frac{3}{\text { Neutral }}$}} & \multirow{2}{*}{\multicolumn{2}{|c|}{$\begin{array}{c} \\
\\
\text { Important }\end{array}$}} & \multirow{2}{*}{\multicolumn{2}{|c|}{$\begin{array}{c}5 \\
\text { Most } \\
\text { important }\end{array}$}} & \multirow{3}{*}{ 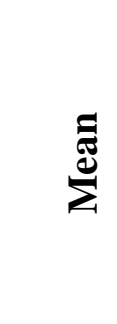 } & \multirow{3}{*}{ 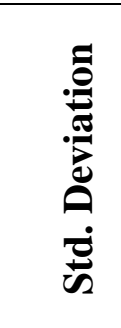 } & \multirow{3}{*}{ 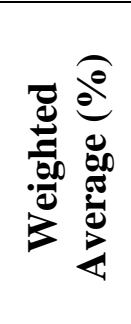 } & \multirow{3}{*}{ 告 } & \multirow{3}{*}{$\frac{\Xi}{\stackrel{\Xi}{\Xi}}$} \\
\hline & & & & & & & & & & & & & & & & \\
\hline & & ర્ટ் & $d^{0}$ & 总 & do & $\underset{d}{\stackrel{D}{\mid c}}$ & $\delta^{\circ}$ & $\underset{d}{\stackrel{D}{\mid c}}$ & $b^{e}$ & ర্ঠ & $b^{e}$ & & & & & \\
\hline 8. & In-room PC & 0 & 0 & 80 & 19 & 228 & 53 & 120 & 28 & 0 & 0 & 3.094 & 0.678 & 61.87 & 13 & \\
\hline 9. & $\begin{array}{l}\text { In-room guest control panel } \\
\text { (e.g., lights, TV, temperature, } \\
\text { blinds, curtains, etc.) }\end{array}$ & 0 & 0 & 0 & 0 & 0 & 0 & 96 & 22 & 332 & 78 & 4.776 & 0.418 & 95.51 & 3 & 10 \\
\hline 10. & Xbox 360 console & 0 & 0 & 0 & 0 & 288 & 67 & 140 & 33 & & & 3.327 & 0.470 & 66.54 & 10 & \\
\hline 11. & bathroom Smart Toilets & 0 & 0 & 171 & 40 & 257 & 60 & 0 & 0 & 0 & 0 & 2.601 & 0.490 & 52.01 & 12 & \\
\hline \multirow[t]{2}{*}{12.} & Flat panel HD Television & 0 & 0 & 0 & 0 & 40 & 9 & 81 & 19 & 307 & 72 & 4.624 & 0.650 & 92.48 & 5 & \\
\hline & $\begin{array}{l}\text { Dimension 3: Business } \\
\text { Essentials }\end{array}$ & & & & & & & & & & & & & & & \\
\hline 1. & $\begin{array}{l}\text { Business center (e.g., computers, } \\
\text { fax and copier machinery, etc.) }\end{array}$ & 0 & 0 & 0 & 0 & 0 & 0 & 40 & 9 & 388 & 91 & 4.907 & 0.291 & 98.13 & 1 & 2 \\
\hline 2. & Express Check-in / Check-out & 0 & 0 & 0 & 0 & 0 & 0 & 48 & 11 & 380 & 89 & 4.888 & 0.316 & 97.76 & 2 & 3 \\
\hline 3. & $\begin{array}{l}\text { Easily Accessible Electronic } \\
\text { Outlets }\end{array}$ & 0 & 0 & 0 & 0 & 0 & 0 & 116 & 27 & 312 & 73 & 4.729 & 0.445 & 94.58 & 4 & \\
\hline 4. & In-room Telephone & 0 & 0 & 0 & 0 & 0 & 0 & 141 & 33 & 287 & 67 & 4.671 & 0.471 & 93.41 & 5 & \\
\hline \multirow[t]{2}{*}{5.} & In-room Alarm Clock & 0 & 0 & 0 & 0 & 0 & 0 & 80 & 19 & 348 & 81 & 4.813 & 0.390 & 96.26 & 3 & 7 \\
\hline & Dimension 4: Internet Access & & & & & & & & & & & & & & & \\
\hline 1. & $\begin{array}{l}\text { In-room High-Speed Internet } \\
\text { Access }\end{array}$ & 0 & 0 & 0 & 0 & 40 & 9 & 101 & 24 & 287 & 67 & 4.577 & 0.657 & 91.54 & 2 & \\
\hline \multirow[t]{2}{*}{2.} & Free HSIA & 0 & 0 & 0 & 0 & 0 & 0 & 72 & 17 & 356 & 83 & 4.832 & 0.375 & 96.64 & 1 & $6^{*}$ \\
\hline & Note: * Mean Repeated & & & & & & & & & & & & & & & \\
\hline
\end{tabular}


Table (5) showed that the mean scores of the respondents were in the first rank: why did you choose this hotel by mean (4.91) and SD (0.22); followed in the next position by dimension (3): Business essentials, with mean (4.80) and SD (0.33); in the third position dimension (4): Internet access by mean 4.70 and SD 0.48. Followed in the fourth position by dimension (2): comfort technologies, with mean (4.14) and SD (0.46); finally, in the fifth position. Dimension (4): Internet access by mean (3.86) and SD (0.39).

\section{Table 5}

Descriptive Analysis of the Respondents' Opinions Regarding the Effect of Applying Technology at the Guest Room on the Guest's Choice of the Hotel ( $\mathrm{n}=$ 428).

\begin{tabular}{|l|l|r|r|r|r|}
\hline \multirow{2}{*}{ No. } & \multicolumn{2}{|c|}{ Dimension } & \multicolumn{2}{c|}{ Mean } & \multicolumn{2}{c|}{ Std. Deviation } \\
\cline { 3 - 6 } & & Statistic & $\begin{array}{c}\text { Std. } \\
\text { Error }\end{array}$ & Statistic & \\
\hline Total SP & Why did you choose this hotel & 4.9196 & .01066 & .22047 & 1 \\
\hline Total FDD & Dimension 1: In-Room Technologies & 3.8616 & .01892 & .39145 & 5 \\
\hline Total SD & Dimension 2: Comfort Technologies & 4.1417 & .02255 & .46644 & 4 \\
\hline Total TD & Dimension 3: Business Essentials & 4.8014 & .01595 & .33007 & 2 \\
\hline Total DFO & Dimension 4: Internet Access & 4.7044 & .02361 & .48842 & 3 \\
\hline
\end{tabular}

\section{H1: applying technology at the guest room has an effect on the guest's choice of the hotel}

The first hypotheses were tested using NPar tests "Kruskal-Wallis test". Test statistics, ${ }^{\text {b }}$ (a. Kruskal Wallis test for the impact of the applying technology at the guest room on the guest's choice of the hotel and b. grouping variable: sp5 "facilities technological amenities"). Results showed that there was strong impact of the facilities technological amenities on the guest's choice of the hotel, with (ChiSquare) values ranging from (80.559) to (243.314), asymp. Sig. (0.000) this indicate there was statistically significant relations. As shown in table (6).

\section{Table 6}

The Effect of Applying Technology at the Guest Room on the Guest's Choice of the Hotel NPar Tests.

\begin{tabular}{|c|c|c|c|c|c|}
\hline \multicolumn{4}{|c|}{ Ranks } & \multicolumn{2}{|c|}{ Test Statistics $^{\text {a,b }}$} \\
\hline & sp5 & $\mathbf{N}$ & Mean Rank & \begin{tabular}{|l|} 
Chi-Square \\
\end{tabular} & \\
\hline \multirow{2}{*}{$\begin{array}{l}\text { Totalsp "Why did you choose } \\
\text { this hotel"? }\end{array}$} & Important & 32 & 16.50 & \multirow{2}{*}{243.314} & \multirow{2}{*}{0.000} \\
\hline & Very Important & 396 & 230.50 & & \\
\hline \multirow{2}{*}{$\begin{array}{l}\text { Totalfdd "Dimension 1: In- } \\
\text { Room Technologies". }\end{array}$} & Important & 32 & 26.50 & \multirow{2}{*}{80.559} & \multirow{2}{*}{0.000} \\
\hline & Very & 396 & 229.69 & & \\
\hline \multirow{2}{*}{$\begin{array}{l}\text { Totalsd "Dimension 2: } \\
\text { Comfort Technologies". }\end{array}$} & $\operatorname{Impc}$ & 32 & 18.00 & \multirow{2}{*}{90.011} & \multirow{2}{*}{0.000} \\
\hline & Very & 396 & 230.38 & & \\
\hline \multirow{2}{*}{$\begin{array}{l}\text { Totaltd "Dimension 3: } \\
\text { Business Essentials". }\end{array}$} & Impo & 32 & 20.50 & \multirow{2}{*}{122.150} & \multirow{2}{*}{0.000} \\
\hline & Very & 396 & 230.18 & & \\
\hline \multirow{2}{*}{$\begin{array}{l}\text { Totaldfo "Dimension 4: } \\
\text { Internet Access". }\end{array}$} & Important & 32 & 20.50 & \multirow{2}{*}{122.747} & \multirow[b]{2}{*}{0.000} \\
\hline & \begin{tabular}{|l|} 
Very Important \\
\end{tabular} & 396 & 230.18 & & \\
\hline
\end{tabular}
a. Kruskal Wallis Test
b. Grouping Variable: sp5 
H2: The top ranking of guest priorities regarding the role of applying technology at the guest room on the guest's choice of the hotel have positive influences in each other.

H3: The guest priorities have positive influence with the guest perception in accordance to the Facilities Technological Amenities.

Table (7) and table (8) showed the correlation matrix among guest top requirements priorities of the effect of applying technology at the guest room on the guest's choice of the hotel. The results revealed that there were significant correlations among many the effect of applying technology at the guest room on the guest satisfaction. The results showed that there were strong correlations between all proposed relation in the conceptual hypotheses, with $(\mathrm{r})$ values ranging from $\left(0.505^{* *}\right)$ to $\left(0.985^{* *}\right)(\mathrm{p}<0.01)$ ** Correlation was significant at the (0.01) level (1-tailed). The obtained correlation values between the guest priorities were in the expected positive direction while the perception was in the negative direction with all the priorities. Based on the results of Pearson correlation analysis which represent proposed linear relationship, all the research hypotheses were supported.

\section{Table 7}

Summary of Correlation Analysis and Hypotheses Testing.

\begin{tabular}{|c|c|c|c|c|c|c|c|}
\hline \multicolumn{8}{|c|}{ Correlations } \\
\hline & & Totalsp & Totalfdd & Totalsd & Totaltd & Totaldfo & $\mathrm{sp5}$ \\
\hline \multirow{2}{*}{$\begin{array}{l}\text { Total sp "Why did you } \\
\text { choose this hotel" }\end{array}$} & Pearson Correlation & 1 & & & & & \\
\hline & Sig. (1-tailed) & & & & & & \\
\hline \multirow{2}{*}{$\begin{array}{l}\text { Total fdd "Dimension 1: } \\
\text { In-Room Technologies" }\end{array}$} & Pearson Correlation & $.644^{* *}$ & 1 & & & & \\
\hline & Sig. (1-tailed) & .000 & & & & & \\
\hline \multirow{2}{*}{$\begin{array}{l}\text { Total sd "Dimension 2: } \\
\text { Comfort Technologies" }\end{array}$} & Pearson Correlation & $.714^{* *}$ & $.981^{* *}$ & 1 & & & \\
\hline & Sig. (1-tailed) & .000 & .000 & & & & \\
\hline \multirow{2}{*}{$\begin{array}{l}\text { Total td "Dimension 3: } \\
\text { Business Essentials" }\end{array}$} & Pearson Correlation & $.825^{* *}$ & $.867^{\text {*** }}$ & $.929^{* *}$ & 1 & & \\
\hline & Sig. (1-tailed) & .000 & .000 & .000 & & & \\
\hline \multirow{2}{*}{$\begin{array}{l}\text { Total dfo "Dimension 4: } \\
\text { Internet Access" }\end{array}$} & Pearson Correlation & $.832^{* *}$ & $.863^{* *}$ & $.923^{* *}$ & $.985^{* *}$ & 1 & \\
\hline & Sig. (1-tailed) & 0.000 & 0.000 & 0.000 & 0.000 & & \\
\hline \multirow{2}{*}{$\begin{array}{l}\text { sp5 "Facilities } \\
\text { Technological Amenities" }\end{array}$} & Pearson Correlation & $0.897^{* *}$ & $0.505^{\text {** }}$ & $0.576^{\text {** }}$ & $0.691^{\text {** }}$ & $0.702^{* *}$ & 1 \\
\hline & Sig. (1-tailed) & 0.000 & 0.000 & 0.000 & 0.000 & 0.000 & \\
\hline
\end{tabular}

\section{Table 8}

Hypothesis Test Summary.

\begin{tabular}{|c|l|c|c|c|}
\hline \multicolumn{1}{|c|}{ Null Hypotheses } & Test & Sig. & Decision \\
\hline 1 & $\begin{array}{l}\text { The distributions of sp5, } \\
\text { totalsp, totalfdd, totaltd and } \\
\text { totaldfd are the same. }\end{array}$ & $\begin{array}{l}\text { Related- samples friedman's } \\
\text { two-way Analysis of } \\
\text { variance by ranks }\end{array}$ & 0.000 & $\begin{array}{c}\text { Reject the null } \\
\text { hypothesis. }\end{array}$ \\
\hline
\end{tabular}




\section{Asymptotic significances are displayed. The significance level is 0.05 .} The Guests' Preferences Regarding the Facilities Technological Amenities Model The process of developing was a ranking model regarding the guests' guest priorities regarding applying technology at the guest room on the guest's choice of the hotel which aim to shed light on the most recurrent preferences of facilities technological amenities from the perspectives of the guests so as to improve the guests' satisfaction. The aim of this model was to shed the light on the most attractive attributes of facilities technological amenities from the perspectives of guests in order to better meet the guest satisfaction (see table 8).

The importance of this ranking model was to provide the perspectives regarding the most important guests' requirements and priorities for facilities technological amenities, in order to better understand the guests' requirements for the role of applying technology at the guest room on the guest's choice of the hotel and trying to meet these requirements, which will lead to guest satisfaction.

From the hospitality industries point of view, facilities technological amenities could also have been included. Generally, guest satisfaction was the feeling of gest that has experienced the service quality and then the judgments of satisfaction are made. There was no doubt that every single hotel need to keep their guests satisfied (Kouzmal, 2016).

\section{Conclusion}

Based upon the data obtained from the questionnaire, it can be concluded that:

In accordance why the guest chooses the hotel the most important ranking positions were the price, quality, the facilities technological amenities, the services, and the location was considered by the majority of guests that the most important attributes.

Regarding the guests' requirements concerning the in-room technologies attributes, the findings showed that the most important ranking positions for the guest perceptions in the investigation were as follows: coffee/tea making facilities, in-room Pay-Per-View (PPV) movies, room facilities, the hair dryer, the iHome with iPod and radio were considered the most important in-room technologies attributes for guests.

Regarding the guests' requirements regarding the comfort technologies attributes, the findings showed that the most important ranking positions for the guest perceptions in the investigation were as follows: the air conditioning, mobile access to hotel website (e.g., Blackberry), the in-room guest control panel (e.g., lights, TV, temperature, blinds, curtains, etc.), the CD/DVD player and the flat panel HD television were considered the most important comfort technologies attributes for guests.

Regarding the guests' requirements regarding the business essentials attributes, the findings showed that the most important ranking positions for the guest perceptions in the investigation were as follows: the business center (Computers, fax and copier machinery, etc.), the express check-in/check-out, in-room alarm clock, room facilities, the easily accessible electronic outlets and the in-room telephone; results showed were considered the most important business essentials attributes for guests. 
Regarding the guests' requirements regarding the internet access attributes, the findings showed that the most important ranking positions for the guest perceptions in the investigation were as follows: free HSIA and in-room high-speed internet access were considered the most important internet access attributes for guests.

\section{Recommendations}

These recommendations might help managers to better meet the guests' requirements in regard to facilities technological amenities and thus to improve guest satisfaction. These recommendations were as follows:

- Hospitality managers should be fully aware of the guests' priorities regarding facilities technological amenities.

- Hospitality managers should be fully aware of guest' priorities regarding the role of applying technology at the guest room on the guest's choice of the hotel.

- In general in accordance why guest chooses the hotel the most important ranking positions should be provided with care of the following the price, quality, the facilities technological amenities, the services and the location were considered by the majority of guests that the most important attributes.

- The in-room technologies attributes should be provided with the following: Coffee/tea making facilities, In-room Pay-Per-View (PPV) movies, room facilities, the hair dryer, the iHome with iPod and radio.

- Comfort technologies attributes should be provided with the following: the air conditioning, mobile access to hotel website (e.g., Blackberry), the in-room guest control panel (e.g., lights, TV, temperature, blinds, curtains, etc.), the CD/DVD player and the flat panel HD television.

- Concerning business essentials attributes should be provided with special care of the following: the business center (Computers, fax and copier machinery, etc.), the express check-in/check-out, in-room alarm clock, room facilities, the easily accessible electronic outlets and the in-room telephone.

- Internet access attributes should be provided with the following: free HSIA and in-room high-speed internet access.

\section{References}

Abbasi, M., Elyas, T. \& Shah, F. (2015). Impact of Individualism \& Collectivism over the Individual's Technology Acceptance Behavior: A Multi-Group Analysis between Pakistan \& Turkey. Journal of Enterprise Information Management, 28(6), 747-768.

Almomani, I., Abdullah, M., Masa'deh, R., Bataine, F. \& Ayoub, A. (2017). The Effect of Environmental Preservation, Advanced Technology, Hotel Image \& Service Quality on Guest Loyalty. International Journal of Business Administration, 8(4), 49. 
Beatson, A., Coote, L. \& Rudd, J. (2006). Determining Consumer Satisfaction \& Commitment through Self Service Technology \& Personal Service Usage. Journal of Marketing Management, 22, 853-82.

Beldona, S. \& Cobanoglu, C. (2007). Importance-Performance Analysis of Guest Technologies in the Lodging Industry. Cornell Hotel \& Restaurant Administration Quarterly, 48- 299.

Beldona, S., Schwartz, Z. \& Zhang, X. (2018). Evaluating Hotel Guest Technologies: Does Home Matter? International Journal of Contemporary Hospitality Management, 30(5), 2327-2342.

Bilgihan, A., Cobanoglu, C. \& Miller, B. (2010). Importance-Performance Analysis of Guest Entertainment Technology Amenities in the Lodging Industry. FIU Review, 28(3), 84-108.

Bilgihan, A., Smith, S., Ricci, P. \& Bujisic, M. (2016). Hotel Guest Preferences of InRoom Technology Amenities. Journal of Hospitality \& Tourism Technology, 7(2), 118-134.

Chathoth, P. (2007). The Impact of Information Technology on Hotel Operations, Service Management \& Transaction Costs: A Conceptual Framework for FullService Hotel Firms. International Journal of Hospitality Management, 26(2), 395-408.

Cobanoglu, C. (2009). Guests' Top 7 Technologies. Hospitality Technology, 13(2).

Cobanoglu, C., Berezina, K., Kasavana, M. \& Erdem, M. (2011). The Impact of Technology Amenities on Hotel Guest Overall Satisfaction. Journal of Quality Assurance in Hospitality \& Tourism, 12(4), 272-288.

Cobanoglu, C., Demirer, I., Kepeci, B. \& Sipahioglu, S. (2006). The Impact of Technology in Hotels: A case Study of Istanbul \& Ankara hotels. An International Journal of Tourism and Hospitality Research, 17(2), 318-322.

Cobos, L., Mejia, C., Ozturk, A. \& Wang, Y. (2016). A Technology Adoption \& Implementation Process in an Independent Hotel Chain. International Journal of Hospitality Management. 57, 93-105.

Dalgic, A. \& Birdie, K. (2020). Smart Hotels \& Technological Applications. Handbook of Research on Smart Technology Application in the Tourism Industry, 323-343.

Dieck, T., Jung, T., Kim, W. \& Moon, Y. (2017). Hotel Guests' Social Media Acceptance in Luxury Hotels. International Journal of Contemporary Hospitality Management, 29(1), 530-550.

Erdem, M., Schrier, T., \& Brewer, P. (2009). Guest Empowerment Technologies. Journal of Hospitality Finance \& Technology Professional, 24(3), 17-19.

Gunarathne, U. (2014). Relationship between Service Quality \& Customer Satisfaction in Sri Lanka Hotel Industry. International Journal of Scientific and Research Publications, 4(11), 1-8.

Higley, J. (2007). Keep Technology Working, Make Guests Happy. Hotel \& Motel Management, 222(11), 6. 
Inge, J. (2006). The Electronic Guestroom. Hospitality Upgrade, 8-22.

Ivanov, S., Webster, C. \& Berezina, K. (2017). Adoption of Robots \& Service Automation by Tourism \& Hospitality Companies. Revista Turismo \& Desenvolvimento, 27(28), 1501-1517.

Ivanov, S., Webster, C. \& Seyyedi, P. (2018). Consumers' Attitudes towards the Introduction of Robots in Accommodation Establishments. Original Scientific Paper, 66(3), 302-317.

Jung, S., Kim, J. \& Farrish, J. (2014). In-room Technology Trends \& their Implications for Enhancing Guest Experiences \& Revenue. Journal of Hospitality \& Tourism Technology, 5(3), 210-228.

Kandampully, J. \& Suhartanto, D. (2000). Customer Loyalty in the Hotel Industry: The Role of Customer Satisfaction \& Image. International Journal of Contemporary Hospitality Management, 12(6), 346-351.

Kansakar, P., Munir, A. \& Shabani, N. (2019). Technology in Hospitality Industry: Prospects \& Challenges. IEEE Consumer Electronics Magazine, 8(3), 60-65.

Kim, J. (2016). An Extended Technology Acceptance Model in Behavioral Intention toward Hotel Tablet Apps with Moderating Effects of Gender and Age. International Journal of Contemporary Hospitality Management, 28(8), 15351553.

Kucukusta, D., Heung, V. \& Hui, S. (2014). Deploying Self-Service Technology in Luxury Hotel Brands: Perceptions of Business Travelers. Journal of Travel \& Tourism Marketing, 31(1), 55-70.

Kuo, N., Chang, K., Chen, M. \& Hsu, C. (2012). Investigating the Effect of Service Quality on Customer Post-Purchasing Behaviors in the Hotel Sector: The Moderating Role of Service Convenience. Journal of Quality Assurance in Hospitality \& Tourism, 13(3), 212-234.

Kouzmal, H. (2016). Ranking the Japanese Guest Priorities for Hospitality Services in Egypt. Paper in Journal of Faulty of Tourism and Hotels, Fayoum University, March, 10(1).

Lan, S. (2014). An Importance-Performance Analysis of Multigenerational Preferences in Guestroom Technology. UNLV Theses, Dissertations, $\begin{array}{llll}\text { Professional Papers } \& & \text { Capstones. }\end{array}$ https://digitalscholarship.unlv.edu/thesesdissertations/2620.

Law, R., Leung, D. \& Cheng, I. (2020). Progression \& Development of Information \& Communication Technology Research in Hospitality \& Tourism. International Journal of Contemporary Hospitality Management, 32(2), 511534.

Lee, H., Lim, H., Jolly, L. \& Lee, J. (2009). Consumer Lifestyles \& Adoption of High-Technology Products: A case of South Korea. Journal of International Consumer Marketing, 21(2), 153-167. 
Lee, S., Barker, S. \& Kandampully, J. (2003). Technology, Service Quality \& Customer Loyalty in Hotels: Australian Managerial Perspectives. Managing Service Quality, 13(5), 423-432.

Lukanova, G. \& Ilieva, G. (2019). Robots, Artificial Intelligence \& Service Automation in Hotels. In S. Ivanov \& C. Webster (Eds.), Robots, Artificial Intelligence \& Service Automation in Travel, Tourism \& Hospitality, 157-183.

Marlin, S. (2008). Modernizing Accommodations. Casino Journal, 21(6), 24-25.

McMullen, S. (2006). Guests Demand Latest, Greatest in-Room Entertainment. Hotel \& Motel Management, 221(5), 36-36.

Munyan, R. (2008). Technology in the Next Generation of Hotels. Lodging Hospitality, 64(16), 78-88.

Prayukvong, W., Sophon, J., Hongpukdee, S. \& Charupas, T. (2007). Customers' Satisfaction with Hotel Guestrooms: A case Study in Ubon Rachathani Province, Thailand. Asia Pacific Journal of Tourism Research, 12(2), 119-126.

Ruiz, M., Gil, I. \& Moliner, B. (2011). Does Technology Make a Difference? Evidence from Spanish Hotels. Service Business, 5(1), 1-12.

Schrier, T., Erdem, M. \& Brewer, P. (2010). Merging Task-Technology Fit \& Technology Acceptance Models to Assess Guest Empowerment Technology Usage in Hotels. Journal of Hospitality \& Tourism Technology, 1(3), 201-217.

Tavitiyaman, P., Zhang, X. \& Yin, W. (2020). How Tourists Perceive the Usefulness of Technology Adoption in Hotels. Interaction Effect of Past Experience \& Education Level, Journal of China Tourism Research, DOI: 10.1080/19388160.2020.1801546.

Verma, R., Victorino, L., Karniouchina, K. \& Feickert, J. (2007). Segmenting Hotel Customers Based on Technology Readiness Index. Cornell Hospitality Report, 7(13), 1-16.

Zabkar, V., Brencic, M. \& Dmitrovic, T. (2009). Modelling Perceived Quality, Visitor Satisfaction \& Behavioral Intentions at the Destination Level. Tourism Management, 31(4), 537-546. 


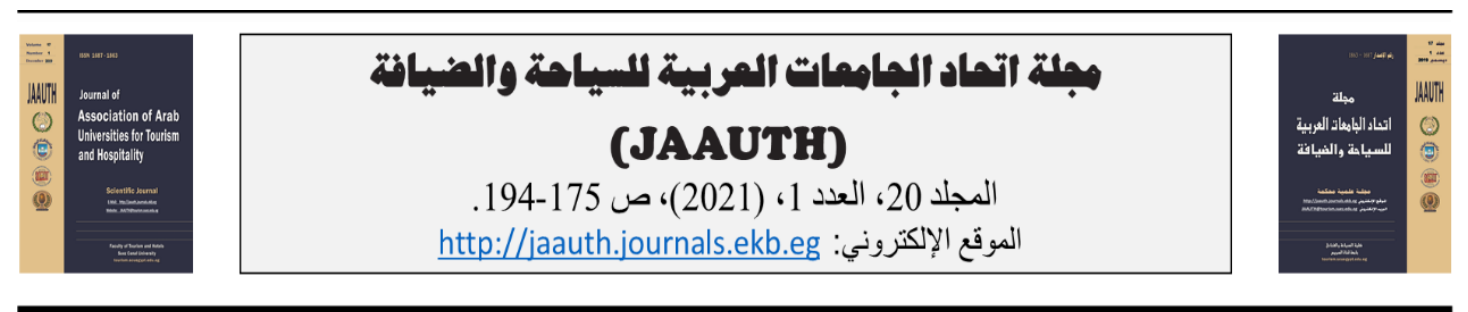

تأثير تطبيق التكنولوجيا في غرف النزلاء على اختيار النزيل للفندق: بالتطبيق على فنادق محافظتي الأقصر وأسوان

هاني عاطف قزمال

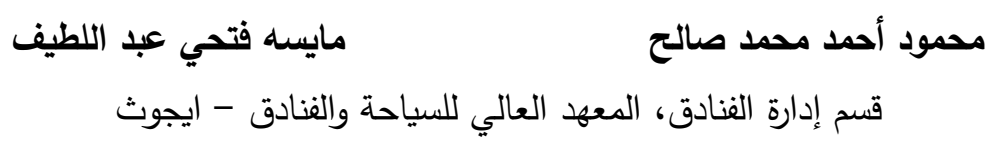

\section{انتشرت فى الآونة الأخيرة الدعوة إلى إعادة النظر في تأثير التكنولوجيا على تجربة}

النزلاء في الفنادق. تم تطبيق التكنولوجيا بثكل تدريجي في صناعة الفنادق على التى

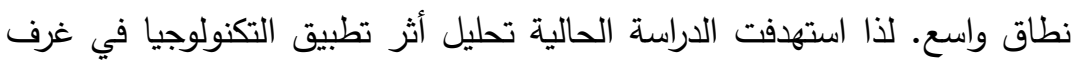
النزلاء على اختيارهم للفندق. تم توزيع استمارة استبيان لجمع البيانات من النزلاء في الفنادق ذات الأربعة والخمسة نجوم في محافظتي الأقصر وأسوان للتحقق من لـن قبول النزلاء للتكنولوجيا في غرفهم. لذا استهدفت هذه الدراسة التعرف على تأثير التكنولوجيا المتقدمة في غرف الفنادق على ولاء النزلاء. حيث فحصت هذه الدراسة التكنولوجيا داخل الغرف وحددت تلك التي يُنظر إليها على أنها ذات أهمية بالغة أنساء لنزلاء الفندق. كما حددت الاختلافات في تفضيلات وتوقعات تكنولوجيا تمكين النزيل عبر الأجيال ووتيرة السفر. علاوة على ذلك، فقد بحثت هذه الدراسة فيما إذا كانت جودة التكنولوجيا داخل الغرف تؤثر على قرار النزلاء في اختيار الفندق. تم جمع البيانات من خلال اللقاءات الثخصية مع النزلاء في الفنادق بالإضافة إلى

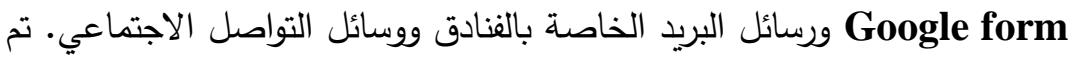
توزيع (500) استمارة استبيان، حيث تم الحصول فقط على (428) عينة صالحة للتحليل الإحصائي. كانت أهم نتائج الدراسة لإرادة أغلب أفراد عينة الدراسة بأن توافر التكنولوجيا الحديثة في غرف النزلاء سوف يؤثر بشكل إيجابي على قرارهم لاختيار الفندق. 